\title{
Diagnosis of the Main Constraints of Rice Production in Nigers Irrigated Perimeters
}

\author{
Issaka Souley, Naroua Illiassou, Souley Mariama Abdoulaye Moussa, Boubacar Gamatché \\ Habibou, Hama Seini Soumana, Djibo Hassoumi.
}

\begin{abstract}
Rice cultivation plays an important part in Niger's people food security. However, despite the significant efforts made to ensure development, the performance of irrigated perimeters still remains below the target yield. In order to propose solutions to improve the productivity of rice-growing sites along the Niger River Valleyr, a diagnostic study of production constraints analyzed the causes of the yield lowess in rice-growing areas. It consisted of: (i) characterizing ten (10) rice-growing perimeters (production, perimeter management, biotic and abiotic constraints), (ii) inventorying major constraints and (iii) proposing possible solutions. The data were collected through interviews with farmers, observations and field studies. It shows that all the perimeters characterized have recorded a low yield $(<8 \mathrm{~T} / \mathrm{ha})$. The main constraints noted are: rice yellow mottle $(27.06 \%$ in the wet season) with incidences reaching $70 \%$, weeds $(22.35 \%)$, absence of improved varieties $(\mathbf{1 7 . 6 5 \%})$, birds $(14.67 \%)$, defective state of infrastructure $(14.67 \%)$, and cultural practices $(11.76 \%)$. Thus, all these constraints must be taken into account, in order to boost rice yields in Niger Republic rice areas.
\end{abstract}

Index Terms: rice irrigated perimeters, production constraints, Rice Yellow Mottle Virus, weeds and irrigation infrastructures

\section{INTRODUCTION}

Irrigated agriculture is the main alternative for ensuring agricultural production in Sahelian countries like Niger, where rain-fed agriculture, characterized by low and random rainfall (FAO, 2011), is unable to meet the food needs of the population, due to climatic hazards and galloping demography. This is why the development of irrigation is considered a key factor in improving the food situation and increasing agricultural incomes (Joanne, 2007). Indeed, rainfall, by its small quantities and its poor distribution in space and time, causes increasingly large deficits in agricultural production, leading to chronic food insecurity. In Niger, since the late 1960s, irrigation development has become a priority for all successive governments (Hammadou et al., 2016). Significant investments have been made to develop and promote, in the Niger River Valley, more than 87 irrigated perimeters, of which 40 are exclusively for double rice cultivation (Dry season and Wet season). Thus, about 15,000 ha of rice per year, with total water control are exploited for the benefit of more than 30,000 farmers (Issaka, 2013 ; Hamadou et al., 2016 ).

Corresponding author: Issaka Souley, BP 175 Tillabéri-Niger, Issaka Souley, Naroua Illiassou, Boubacar Gamatché Habibou, Hama Seini Soumana and Djibo Hassoumi, Boubakar Bâ University of Tillabéri, BP 175 Tillabéri-Niger :

Souley Mariama Abdoulaye Moussa, Niger Republic Industry Ministry, BP 11700 Niamey, Niger
This contributes significantly to the food security of the population. Indeed, rice (Oryza sp.) plays a major role in feeding rural and urban households in Africa, and is a strategic and priority product for food security in developing countries like Niger Republic (Seck et al., 2012). It is the most common cereal in the world after wheat and accounts for $20 \%$ of cereal consumption (FAO, 2016). Rice is consumed by more than half of the world's population (Khush, 2005). Rice is produced in about 110 countries, to varying degrees, and is used for many other uses, including animal feed, industry and pharmaceuticals (Thibaud and Bonneau, 2001; FAO, 2017).

In Niger, rice is the third largest cereal after millet and sorghum in terms of sown and production (Faivre-Dupaigre et al., 2006; Sido et al., 2018). The national production in paddy is 144,814 tons; it covers only $20 \%$ of rice needs (ME, 2019). The country remains dependent on imports, climatic hazards and production constraints causing cyclical food crises (FAO, 2011), despite the crucial role that rice plays in food security and poverty reduction.

Despite its economic importance, rice cultivation and production in Niger, as in the rest of the world, are severely affected by many unfavorable factors (Issaka, 2013). These include unfavorable climatic conditions, poor soil quality, inefficiency of irrigation infrastructures, parasites (viruses, bacteria, fungi), water deficit, seed quality and effects of insect and pests (Nwilene et al., 2009). In general, these multiple constraints prevent rice perimters from achieving their objectives, including: (i) be economically viable and (ii) contribute significantly to the coverage of the population food needs in rice; constraints resulting in low yields that can lead farmers to abandon their plots altogether (Issaka, 2013). Four of these constraints have already been reported as major in Niger: (i) the narrow genetic base of the sown varieties (Issaka et al., 2012a), (ii) labour constraint, (iii) low water in the river and (iv) fertilizer supply (Hamadou et al., 2016). Also, despite the significant financing and supervision efforts deployed to guarantee development and promote irrigated rice cultivation in the Niger River valley, with two rice harvests per year, the performance of irrigated areas is still below the target (ME, 2019). A diagnostic study of the main constraints of rice production is therefore necessary to understand the problems of Niger River Valley's rice perimeters low yields. The study consisted in diagnosing rice production constraints under the cultivation conditions of the dry and wet seasons 2018 of 10 perimeters, in order to contribute to the improvement of these sites productivity. 


\section{MATERIALS AND METHODS}

\section{Study area}

The study involved ten (10) double-rice-growing perimeters situated along the Niger River Valley (Table 1). These sites have a wide geographical distribution in rice ecology and are located on both sides of the two banks of the Niger River, the country's rice-growing area per excellence (Figure 1).

\begin{tabular}{|c|c|c|c|c|c|}
\hline $\mathrm{S} / \mathbf{N}$ & Perimeters & Ecology & Rice season & GPS informations & Producer number \\
\hline 1 & Say 2 & Irrigated & $\begin{array}{l}\text { DS } 2018 \\
\text { WS } 2018\end{array}$ & $\mathrm{~N} 13^{\circ} 05^{\prime} 55^{\prime \prime} ; \mathrm{E} 2^{\circ} 22^{\prime} 24^{\prime \prime}$ & 502 \\
\hline 2 & Say 1 & Irrigated & $\begin{array}{l}\text { DS } 2018 \\
\text { WS } 2018\end{array}$ & $\mathrm{~N} 13^{\circ} 06^{\prime} 28^{\prime \prime} ; \mathrm{E} 2^{\circ} 21^{\prime} 46^{\prime \prime}$ & 712 \\
\hline 3 & Sébéri & Irrigated & $\begin{array}{l}\text { DS } 2018 \\
\text { WS } 2018\end{array}$ & $\mathrm{~N} 13^{\circ} 17^{\prime} 56^{\prime \prime} ; \mathrm{E} 2^{\circ} 20^{\prime} 57^{\prime \prime}$ & 1100 \\
\hline 4 & N'dounga 3 & Irrigated & $\begin{array}{l}\text { DS } 2018 \\
\text { WS } 2018\end{array}$ & $\mathrm{~N} 13^{\circ} 21^{\prime} 02^{\prime \prime} ; \mathrm{E} 2^{\circ} 15^{\prime} 00^{\prime \prime}$ & 359 \\
\hline 5 & Saga & Irrigated & $\begin{array}{l}\text { DS } 2018 \\
\text { WS } 2018\end{array}$ & $\mathrm{~N} 13^{\circ} 28^{\circ} 06^{\prime \prime} ; \mathrm{E} 2^{\circ} 09^{\prime} 00^{\prime \prime}$ & 1081 \\
\hline 6 & Kirkissoye & Irrigated & $\begin{array}{l}\text { DS } 2018 \\
\text { WS } 2018\end{array}$ & $\mathrm{~N} 13^{\circ} 29^{\prime} 15^{\prime \prime} ; \mathrm{E} 2^{\circ} 06^{\prime} 93^{\prime \prime}$ & 365 \\
\hline 7 & $\begin{array}{l}\text { Karey } \\
\text { Gorou }\end{array}$ & Irrigated & $\begin{array}{l}\text { DS } 2018 \\
\text { WS } 2018\end{array}$ & $\mathrm{~N} 13^{\circ} 32^{\prime} 55^{\prime \prime} ; \mathrm{E} 1^{\circ} 59^{\prime} 56^{\prime \prime}$ & 437 \\
\hline 8 & Lossa & Irrigated & $\begin{array}{l}\text { DS } 2018 \\
\text { WS } 2018\end{array}$ & $\mathrm{~N} 13^{\circ} 55^{\prime} 16^{\prime \prime} ; \mathrm{E} 1^{\circ} 34^{\prime} 17^{\prime}$ & 417 \\
\hline 9 & Toula & Irrigated & $\begin{array}{l}\text { DS } 2018 \\
\text { WS } 2018\end{array}$ & $\mathrm{~N} 14^{\circ} 11^{\prime} 49^{\prime \prime} ; \mathrm{E} 1^{\circ} 27^{\prime} 60^{\prime \prime}$ & 965 \\
\hline 10 & Diomona & Irrigated & $\begin{array}{l}\text { DS } 2018 \\
\text { WS } 2018\end{array}$ & $\mathrm{~N} 14^{\circ} 27^{\prime} 19^{\prime \prime} ; \mathrm{E} 1^{\circ} 6^{\prime} 13^{\prime \prime}$ & 1560 \\
\hline & & & & Total & 7498 \\
\hline
\end{tabular}

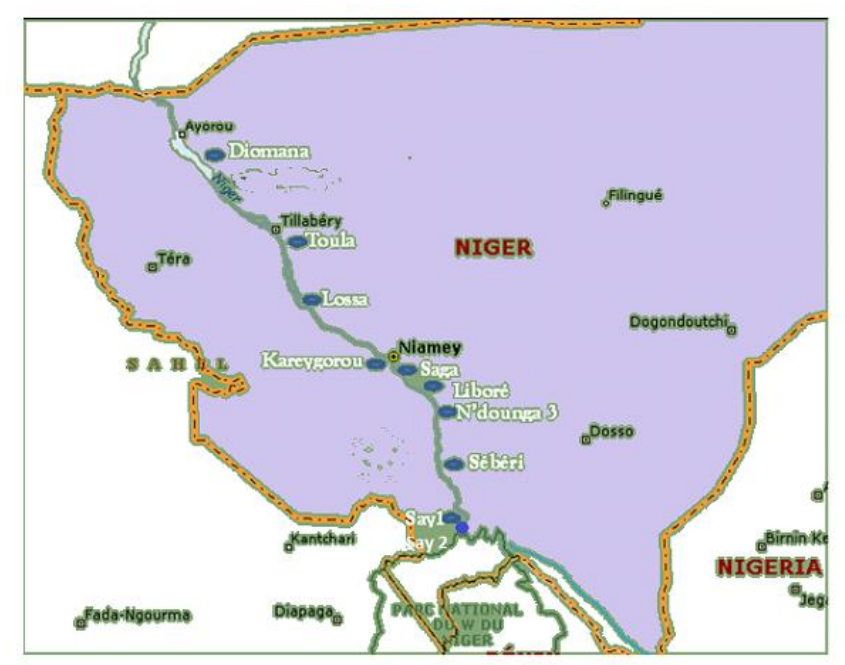

Figure 1 : Localisation géographique des sites riz icoles prospectés

\section{Data collection and analysis}

Prospecting was carried out in the selected sites. It consisted of inventorying the main rice varieties sown and identifying the different constraints of rice production.

To inventory the constraints of rice production in the river valley, ten (10) rice perimeters of the 40 present in the country were sampled, or $25 \%$ of the sites sown and exploited by 7498 farmers. About ten percent $(10 \%)$ of the farmers in each selected perimeter were randomly selected to participate in the survey; or 545 farmers.

Different ranges of production constraints, identified by the producers themselves, were first inventoried. So, a survey sheet addressed to farmers helped to collect information on: the main varieties sown performance, the mode of production, the management of the perimeters and the various constraints of production (state of hydraulic infrastructure, pests and diseases). Then, direct observations and field studies were carried out to verify both the information collected during the interviews and estimate the effects of major constraints.

Estimation of the importance of biotic and abiotic constraints To assess the extent of the biotic constraints, the study mainly estimated the incidence of the dominant disease, the rice yellow mottle, and tested for the presence of the virus responsible (Rice Yellow Mottle Virus, RYMV), through biological tests of leaf samples collected during prospecting on the sensitive rice variety IR1529-680-3-1. The estimation of the disease incidence consisted first of visiting all selected rice perimeters, counting the sites that are infected and assessing their infestation levels. Incidences were estimated by counting, on three lines (spaced $20 \mathrm{~cm}$ apart) taken at random in a heavily infested field $(0.25 \mathrm{ha})$, the number of sick and healthy leaves to determine the highest level of infection. To estimate the low level of the incidence, the process was the same, with the difference that the field concerned is weakly infested (Cochran and Cochran, 1977; Konaté et al., 1997).

The biological tests consisted of rubbing the leaves of young rice plants, 21 days old after sowing, with the grind prepared with each of the collected leaf samples.

The presence of weeds (host-reservoir of RYMV) in and around the plots prospected was also verified, through a summary inventory of said weeds in both dry and wet seasons. The effects of granivorous birds on rice cultivation at the same times have also been recorded, through the estimation of production losses due. The effects of water deficits in the dry countryside and flooding in the wet season were also noted.

Verification of the hydraulic infrastructures state

The state of the hydraulic infrastructures (pumps, channels, canals, drains, etc.) has been the subject of both surveys among producers and visual observation of the field. Indeed, the hydraulic infrastructures of various sites were visited to see their physical and functional state. Also, the producers' responses about these infrastructures made it possible to understand the role of production constraints played by the said infrastructures.

\section{RESULTS}

\section{Monograph of prospected perimeters}

Table 2 gives the characteristics of the ten perimeters prospected. 450 farmers (Of the 545 farmers selected) participated actually in the survey, or $82.56 \%$. As for the size of the perimeters, it varies from one site to another; the sites of Saga (372 ha) and Sébéri (293 ha) being the large and, the perimeter of N'dounga 3 (89 ha), the smallest. The yields obtained during the two seasons are recorded in Table 3. It shows that yields are low at all perimeters $(<8 \mathrm{~T} / \mathrm{ha})$. They vary from one campaign to another and are even lower in the dry season than in the wet one.

The inventory of the main varieties grown at the ten sites (Table 4) showed that only two to three varieties are predominantly grown. These are the varieties IR1529-680-3-1, grown mainly in the dry season, the Kogoni 91-1 variety called Gambiaka which is mainly practiced in the wet season and the Mai-aléwa and wayhidjo varieties 
practiced respectively on three (Say 1 and 2 and N'dounga3) and two (Saga and Kirkissoye) sites.

\begin{tabular}{|c|c|c|c|c|c|c|}
\hline S/N & Perimeters & Ecology & Rice season & Area (ha) & Numbers of farm & $\begin{array}{c}\text { Samples } \\
\text { (Numbers) }\end{array}$ \\
\hline \multirow{2}{*}{1} & \multirow{2}{*}{ Say 2} & \multirow{2}{*}{ Irrigated } & DS 2018 & 181 & \multirow{2}{*}{502} & \multirow{2}{*}{45} \\
\hline & & & WS 2018 & 125,62 & & \\
\hline \multirow{2}{*}{2} & \multirow{2}{*}{ Say 1} & \multirow[t]{2}{*}{ Irrigated } & DS 2018 & 228,83 & \multirow{2}{*}{712} & \multirow{2}{*}{50} \\
\hline & & & WS 2018 & 178,06 & & \\
\hline \multirow{2}{*}{3} & \multirow{2}{*}{ Sébéri } & \multirow[t]{2}{*}{ Irrigated } & DS 2018 & 244,28 & \multirow{2}{*}{1100} & \multirow{2}{*}{80} \\
\hline & & & WS 2018 & 293,61 & & \\
\hline \multirow{2}{*}{4} & \multirow{2}{*}{ N'dounga 3} & Irrigated & DS 2018 & 89,75 & \multirow{2}{*}{359} & \multirow{2}{*}{30} \\
\hline & & & WS 2018 & 89,74 & & \\
\hline \multirow[b]{2}{*}{5} & \multirow{2}{*}{ Saga } & Irrigated & DS 2018 & 334,75 & \multirow{2}{*}{1081} & \multirow{2}{*}{70} \\
\hline & & & WS 2018 & 372,5 & & \\
\hline \multirow{2}{*}{6} & \multirow{2}{*}{ Kirkissoye } & Irrigated & DS 2018 & 91,97 & \multirow{2}{*}{365} & \multirow{2}{*}{35} \\
\hline & & & WS 2018 & 91,23 & & \\
\hline \multirow{2}{*}{7} & \multirow{2}{*}{ Karey Gorou } & Irrigated & DS 2018 & 132,83 & \multirow{2}{*}{437} & \multirow{2}{*}{40} \\
\hline & & & WS 2018 & 132,5 & & \\
\hline \multirow{2}{*}{8} & \multirow{2}{*}{ Lossa } & Irrigated & DS 2018 & 104,26 & \multirow{2}{*}{417} & \multirow{2}{*}{40} \\
\hline & & & WS 2018 & 122,52 & & \\
\hline 9 & Toula & Irrigated & DS 2018 & 243,74 & 965 & 65 \\
\hline & & & WS 2018 & 241,25 & & \\
\hline 10 & Diomona & Irrigated & DS 2018 & 390,05 & 1560 & 90 \\
\hline & & & WS 2018 & 391,69 & & \\
\hline
\end{tabular}

Table 3: Rice production and yield in prospected perimeters

\begin{tabular}{|c|c|c|c|c|c|}
\hline S/N & Perimter & Rice season & Area (ha) & $\begin{array}{l}\text { Rice production } \\
\text { (T/paddy) }\end{array}$ & Yield (T/ha) \\
\hline \multirow{2}{*}{1} & \multirow[b]{2}{*}{ Say 2} & DS 2018 & 181 & 1320,25 & 7,29 \\
\hline & & WS 2018 & 125,62 & 668 & 5,32 \\
\hline \multirow{2}{*}{2} & \multirow{2}{*}{ Say 1} & DS 2018 & 228,83 & 1431,00 & 6,25 \\
\hline & & WS 2018 & 178,06 & 782,33 & 4,39 \\
\hline \multirow{2}{*}{3} & \multirow{2}{*}{ Sébéri } & DS 2018 & 244,28 & 1124,88 & 4,60 \\
\hline & & WS 2018 & 293,61 & 1488,98 & 5,07 \\
\hline \multirow{2}{*}{4} & \multirow{2}{*}{ N'dounga 3} & DS 2018 & 89,75 & 502,9 & 5,60 \\
\hline & & WS 2018 & 89,74 & 499,07 & 5,56 \\
\hline \multirow{2}{*}{5} & \multirow{2}{*}{ Saga } & DS 2018 & 334,75 & 2072,00 & 6,19 \\
\hline & & WS 2018 & 372,5 & 1769,90 & 4,75 \\
\hline \multirow{2}{*}{6} & \multirow{2}{*}{ Kirkissoye } & DS 2018 & 91,97 & 470,91 & 5,12 \\
\hline & & WS 2018 & 91,23 & 554,8 & 6,08 \\
\hline \multirow{2}{*}{7} & \multirow{2}{*}{ Karey Gorou } & DS 2018 & 132,83 & 657 & 4,95 \\
\hline & & WS 2018 & 132,5 & 630 & 4,75 \\
\hline \multirow{2}{*}{8} & \multirow{2}{*}{ Lossa } & DS 2018 & 104,26 & 599,4 & 5,75 \\
\hline & & WS 2018 & 122,52 & 694,63 & 5,67 \\
\hline \multirow{2}{*}{9} & \multirow{2}{*}{ Toula } & DS 2018 & 243,74 & 1367,38 & 5,61 \\
\hline & & WS 2018 & 241,25 & 1023,71 & 4,24 \\
\hline \multirow{4}{*}{10} & \multirow{2}{*}{ Diomona } & DS 2018 & 390,05 & 2679,00 & 6,87 \\
\hline & & WS 2018 & 391,69 & 2021,00 & 5,16 \\
\hline & & & rage yield & & 5,46 \\
\hline & & & dium ecartype & & 0,78 \\
\hline
\end{tabular}

Table 4: Inventory of the main emblaved varieties

\begin{tabular}{lccccc}
\hline \multirow{2}{*}{ Sites } & Varieties & \multicolumn{5}{c}{ Emblaved varieties } \\
\cline { 3 - 6 } & number & IR 1529-680-3-1 & Kogoni 90-1 & May a léwa & Wayhidjo \\
\hline Say2 & 3 & $\mathrm{x}$ & $\mathrm{x}$ & $\mathrm{x}$ & \\
Say1 & 3 & $\mathrm{x}$ & $\mathrm{x}$ & $\mathrm{x}$ & \\
Sébéri & 2 & $\mathrm{x}$ & $\mathrm{x}$ & & \\
N'dounga 3 & 3 & $\mathrm{x}$ & $\mathrm{x}$ & $\mathrm{x}$ & \\
Saga & 3 & $\mathrm{x}$ & $\mathrm{x}$ & & $\mathrm{x}$ \\
Kirkissoye & 3 & $\mathrm{x}$ & $\mathrm{x}$ & & $\mathrm{x}$ \\
Karey gorou & 2 & $\mathrm{x}$ & $\mathrm{x}$ & & \\
Lossa & 2 & $\mathrm{x}$ & $\mathrm{x}$ & & \\
Diomana & 2 & $\mathrm{x}$ & $\mathrm{x}$ & & \\
Toula & 2 & $\mathrm{x}$ & $\mathrm{x}$ & & \\
\hline
\end{tabular}

The main constraints of rice production identified by farmers According to the farmers surveyed, three categories of constraints impact rice production in the prospected sites (Table 5). These are biotic, abiotic and institutional constraints. Their impacts vary from one rice season to another. Overall, biotic stresses are greater in the wet season $(74.12 \%)$ than in the dry season $(40 \%)$ and abiotic stresses are more predominant in the dry season $(53.33 \%)$ than in the wet season (23.53). As for institutional constraints, their effects are small on production (6.25\% in DS and $2.39 \%$ in WS).

Among the biotic constraints, the rice yellow mottle remains the major constraint $(27.06 \%$ in Wet Season), followed by weeds (22.35\% in Dry Season) and the absence of improved varieties (17.65\%). Among the abiotic constraints, the defective state of infrastructures (14.67\% in DS) and cultivation practices $(11.76 \%$ in WS) represent the most unfavorable factors for rice production.

\begin{tabular}{|c|c|c|c|c|}
\hline Types of production constraints & Dry season (DS) & Wet season (WS) & $\%$ in DS & $\%$ in WS \\
\hline Biotic constraints: & 150 & 315 & 40,00 & 74,12 \\
\hline Diseases (Rice yellow mottle, etc.) & 35 & 115 & 9,33 & 27,06 \\
\hline Lack of improved and adapted varieties & 45 & 75 & 12,00 & 17,65 \\
\hline Birds/insects & 55 & 30 & 14,67 & 7,06 \\
\hline Weeds & 15 & 95 & 4,00 & 22,35 \\
\hline Abiotic constraints: & 200 & 100 & 53,33 & 23,53 \\
\hline Culturales practices & 35 & 50 & 9,33 & 11,76 \\
\hline Practice of individual nurseries & 25 & 10 & 6,67 & 2,35 \\
\hline Inputs & 45 & 5 & 12,00 & 1,18 \\
\hline Water Toner & 40 & 5 & 10,67 & 1,18 \\
\hline $\begin{array}{l}\text { State of hydraulic infrastructures and } \\
\text { equipments }\end{array}$ & 55 & 30 & 14,67 & 7,06 \\
\hline Institutional constraints: & 25 & 10 & 6,67 & 2,35 \\
\hline Lax management & 5 & 2 & 1,33 & 0,47 \\
\hline Royalties and other receivables & 15 & 3 & 4,00 & 0,71 \\
\hline $\begin{array}{l}\text { Provision of adequate agricultural } \\
\text { equipment }\end{array}$ & 5 & 5 & 1,33 & 1,18 \\
\hline Total & 375 & 425 & 100 & 100,00 \\
\hline
\end{tabular}

Nocuity of rice yellow mottle and weeds on rice production

Field observation and biological tests carried out by mechanical inoculation of the sensitive variety IR1529-680-3-1 with the grinding of the leaf samples taken showed that the rice yellow mottle is present on all the selected sites, except that of Lossa.; biological tests revealed typical symptoms of rice yellow mottle (Figure 2). The disease was greater in the wet season than in the dry season and its incidence varies by site (Table 6). Thus, the sites of Sébéri, Saga, Kirkissoye and Toula were the most infected (at least 10 infected samples per site) while the remaining perimeters were weakly infected.

Therefore, the results of the survey and field prospecting have shown that weeds are more common in WS than in DS. Indeed, weeds are very present in and around rice plots during this season.

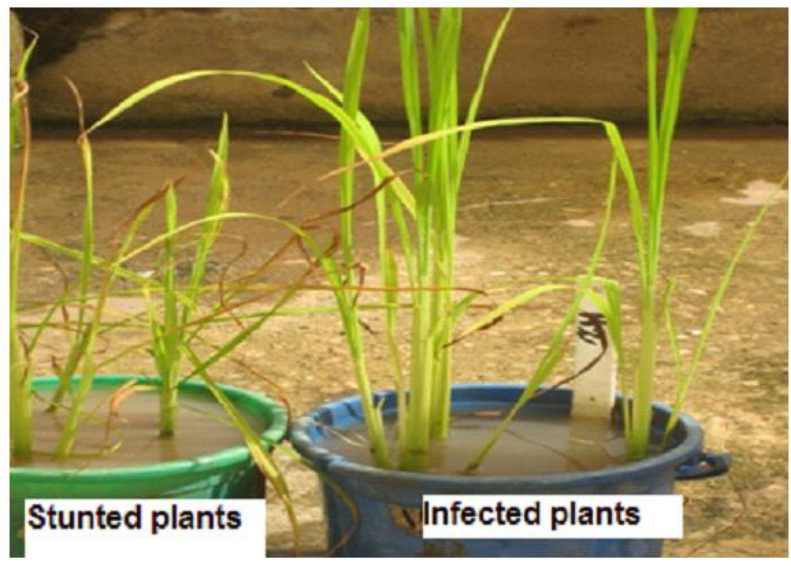

Figure 2: Typical symptoms of RYMV

\section{State of infrastructures and cultivation practices application level}

The inspection of the hydraulic infrastructure mainly revealed the insufficiency and/or ageing as well as the defect of the hydraulic infrastructure and pumping equipment. The canals and drains are also either completely grassed (Figure 3), due to lack of cleaning, or degraded (Figure 4); resulting in a decrease in the efficiency of the irrigation roads, causing huge water losses upstream and downstream of irrigation. Therefore, the non-application of good cultivation practices is 
another significant constraint on rice production. Indeed, the field inspection found, among other things, non-compliant ploughing, transplanting and late fertilizer application.

Table 6: Incidence and Production Losses Recorded in prospected perimeters

\begin{tabular}{lcccc}
\hline Perimeters & $\begin{array}{c}\text { Incidence in Wet Season } \\
(\%)\end{array}$ & $\begin{array}{c}\text { Incidence in Dry Season } \\
(\mathbf{\%})\end{array}$ & \multicolumn{2}{c}{ Collected isolates } \\
\cline { 3 - 5 } & 5 & 25 & DS & WH \\
\hline Say2 & 25 & 30 & 0 & 2 \\
Say1 & 10 & 50 & 2 & 3 \\
Sébéri & 5 & 10 & 1 & 10 \\
N'dounga 3 & 25 & 55 & 0 & 1 \\
Saga & 15 & 60 & 3 & 12 \\
Kirkissoye & 10 & 35 & 1 & 13 \\
Karey gorou & 0 & 10 & 1 & 3 \\
Lossa & 25 & 35 & 0 & 0 \\
Diomana & 40 & 70 & 2 & 3 \\
Toula & $\mathbf{1 6 0}$ & $\mathbf{3 8 0}$ & $\mathbf{1 8}$ & $\mathbf{6 2}$ \\
\hline Total & & &
\end{tabular}

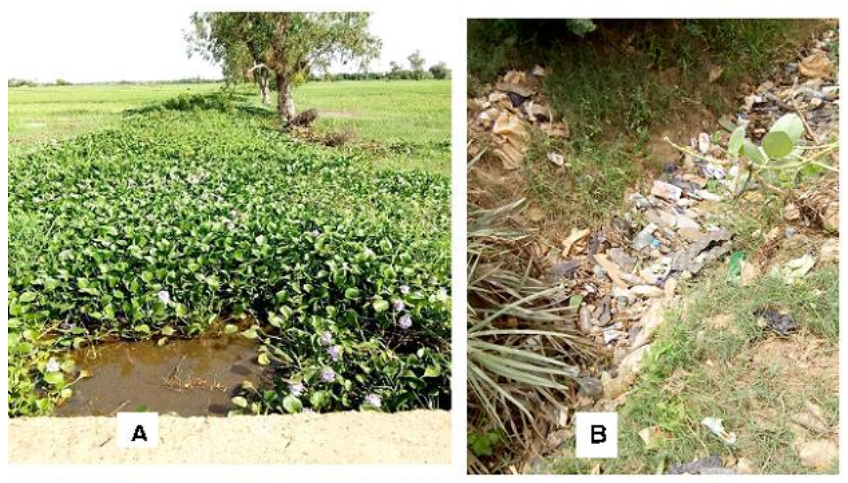

Figure 3: Grassing of canals and drains in wet season at Kirkissoye (A: main drain and B secondary canal).

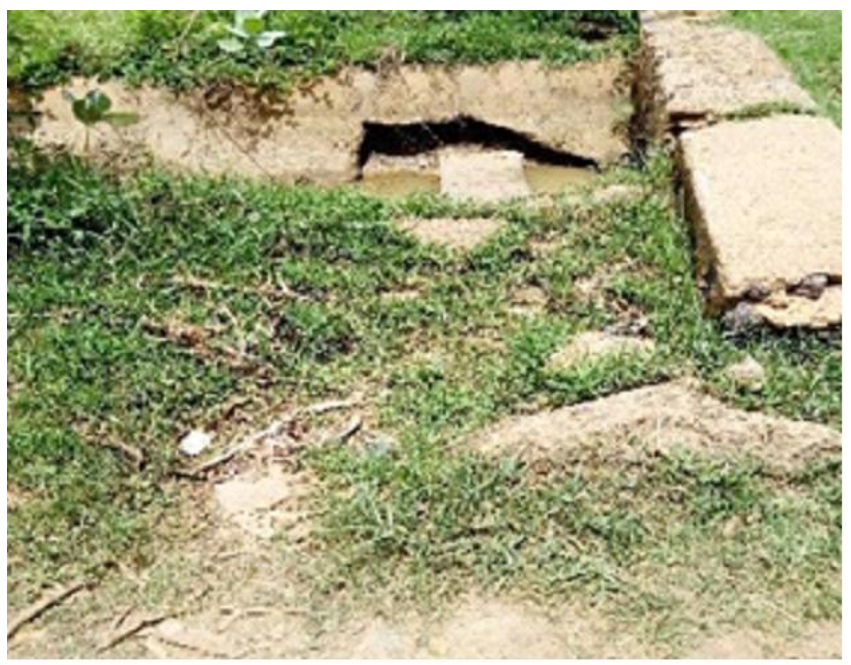

Figure 4: Degradation of irrigation canals

\section{DISCUSSION}

The yields obtained during the two seasons are low in all rice perimeters $($ average $=5.16 \mathrm{~T} / \mathrm{ha}$ ) but variable from one season to another, with even lower values in the dry season than in the wet one. These low yields could be explained by the permanent presence and high frequency of many constraints on rice production. Similar results involving various constraints of double rice cultivation in Niger have previously been reported in the same by Hamadou et al. (2016).

The results of the inventory of the main cultivated varieties indicate that only two to three varieties are mainly emblaved. This suggests a strong narrowness of the genetic basis of the varieties used; narrowness which could be detrimental to rice cultivation, since none of these varieties is really adapted to the present constraints. This narrowness of the genetic basis of varieties sown in Niger has been previously reported by Issaka et al., (2012a), having shown that only four varieties of rice are practiced there. The results of the study suggest a narrower genetic basis than that reported by these authors. Sy et al., (2001) also proved the effect of the genetic basis of varieties sown in some West Africa.

According to the results of the farmers' survey, two main categories of constraints (biotic and abiotic) impact rice production in the prospected sites. These are biotic constraints (Rice yellow mottle, weeds and absence of improved rice varieties) estimated at $74.12 \%$ in the wet season and abiotic constraints (defective state of hydraulic infrastructures and cultivation practices) representing $53.33 \%$ of constraints in the dry season. This suggests that Niger's rice production still faces real challenges that it urges to take into account. However, the study did not consider as a constraint the supply of fertilizers as reported by Hamadou et al., (2016) and Mossi et al., (2017). These authors have shown that the non-availability of quality fertilizers is one of the main obstacles to the productivity of rice sites in Niger republic. However, the present results are similar to those of Hamadou et al., (2016) regarding the lack of improved varieties and the low yield in double rice cultivation practiced.

The estimate of the impacts and the results of the biological tests showed that the rice yellow mottle is present on $90 \%$ of the selected sites; which sites are dominated by the significant presence of weeds, especially in the wet season. This suggests that rice yellow mottle remains a major constraint in rice production, followed by weeds. The disease was greater in the wet season than in the dry season and its incidence varied by site. Similar results have been reported in Niger's rice environment by Issaka et al., (2012a) and Issaka et al., (2012b). Thus, these authors explained the frequency and importance of disease and weeds in the wet season on the one hand by the large proliferation of vectors and on the other hand, by the improvement of habitat and development conditions.

As for water infrastructures, the inspection revealed above all the insufficiency and/or ageing of hydraulic infrastructure and pumping equipment as well as the degradation and grassing of irrigation system. This could lead to the inefficiency of the irrigation system due to continuous and uncontrolled water losses. This is also likely to increase the redevance and other credits for the maintenance of canals and drains.

\section{V.CONCLUSION}

Five major constraints of rice production were identified. In order of importance (negative impact) these are: (i) rice yellow mottle due to RYMV, (ii) weeds, (iii) lack of improved varieties, (iv) inefficiency of the irrigation and pumping system and poor application of cultivation practices. 
The impact of these constraints has been confirmed by observations and field studies. Thus, the taking into account and controlling of all these constraints would help to stop or sharply reduce the observed production declines, in order to move towards self-sufficiency in rice.

\section{CONFLICTS'INTERETS}

The authors declare that they have no conflicts of interest.

\section{AUTHORS' CONTRIBUTIONS}

IS, NI and SMAM implemented the protocol, conducted prospecting and sampling, set up assays, collected, analyzed and interpreted the data. BGH, HSS and DH contributed to the sampling and data analysis. All authors wrote and corrected the manuscript before and after submission.

\section{ACKNOWLEDGMENTS}

The authors thank the Agricultural Productivity Program in West Africa (WAAPP-Niger), for its funding. They also thank all the farmers and managers of the studied sites and cooperatives, for their multifaceted support in the conduct of this study.

\section{REFERENCES}

[1] Amir S.Y, Guéro Y, Mella M. T, Abdourahamane I. N. 2018 Évaluation participative des variétés de riz en riziculture au tour des mares au Niger : cas des communes rurales d'Imanan et de Tondikandia. Journal of Applied Biosciences 127 : 12857-12866.

[2] Cochran, Cochran WG. 1977. Samples techniques (3rd Ed.). Wiley, New york. 428 p.

[3] Faivre-Dupaigre B, Hermelin B, Ribier V. 2006. Quelles marges de manœuvre pour les produits agricoles sensibles dans le cadre des APE ? Séminaire FARM, 27-29 novembre 2006.

[4] FAO, 2011. Etat des lieux de la riziculture au Niger: les contraintes au développement de la riziculture. 76 p. http://www.fao.org.

[5] FAO 2016. Situation mondiale de l'alimentation et de l'agriculture : Atténuation des effets du changement climatique. http://www.fao.org

[6] FAO 2017. L'état des lieux de la sécurité alimentaire dans le monde : renforcer la résilience pour favoriser la paix et la sécurité dans le monde. 144p. http://www.fao.org

[7] Hamadou S. Mossi M, I., Kanfidéni, B., 2016. Irrigation et intensification de la production agricole au Sahel : perceptions paysannes sur la double riziculture au Niger. Journal of Applied Biosciences 107: 10439-10449. 11 Pages.

[8] Issaka S, Basso A, Sorho F, Onasanya A, Haougui A, Sido AY, Aké S, Fargette D, Séré Y. 2012a. Diagnosis and Importance of Rice Yellow Mottle Disease Epidemics in Niger Republic. Journal of Applied Biosciences 50: 3501-3511. www.m.elewa.org.

[9] Issaka S, Onasanya A, Basso A, Sorho F, Haougui A, Sido AY, Ake S, Fargette D, Sere Y. 2012b. Existence of several pathotypes among Rice Yellow Mottle Virus (RYMV) isolates collected in Niger republic. Trends in Applied Sciences Research 7 (1): 32-45. DOI: https://doi.org/10.3923/tasr.2012.32.45.

[10] Issaka S. 2013. La panachure jaune du riz en Afrique de l'Ouest : L'pidémiologie, distribution, pathogénie et variabilité du Rice Yellow Mottle Virus (RYMV) au Niger. Thèse de doctorat unique de l'Université Félix Houphouët-Boigny de Cocody, Côte d'Ivoire. 156 P.

[11] Joanne C. L., 2007. La petite irrigation privée dans le sud Niger : potentiels et contraintes d'une dynamique locale Le cas du sud du Département de Gaya, Mémoire juillet 2007. Unil université de Lausanne. Institut de géographie. 149 p.

[12] Khush, G. S. 2005. What it will take to feed 5.0 billion rice consumers in 2030. Plant Mol. Biol. 59 (1) : 1-6.

[13] Konate G, Traore O, Coulibaly MM. 1997. Characterization of rice yellow mottle virus isolatesin Sudano-Sahelian areas. Arch. $\begin{array}{lll}\text { Virol. } 142 & (6): 1117-1124 . & \text { DOI : }\end{array}$ https://doi.org/10.1007/s007050050146.
[14] Ministère de l'Energie. 2019. Subvention de l'énergie dans les aménagements hydro-agricole du Niger. Novembre 2019.

[15] Mossi M. I, Alou H. A, Haougui, Souleymane A and Ibro G. 2017. Normes techniques et pratiques locales des producteurs dans les périmètres de Toula et Bonféba au Niger. African Crop Science Journal 25 (4) : 441 - 456.

[16] Nwilene FE. 1999. Current status and management of insect vectors of Rice yellow mottle virus (RYMV) in Africa. Insect Sci. and Appli., 19 : (2-3) 179-185. https://doi.org/10.1017/S1742758400019445.

[17] Seck, P. A., Diagne, A., Mohanty, S. and Wopereis, M.C.S. 2012. Crops that feed the world 7: rice. Food Security 4 (1) : 7-24.

[18] Sy AA, Séré Y. 2001. Variétés majeures sous écosystème rizicole sahélien : Profil de résistance au virus de la marbrure jaune (RYMV) et réajustement stratégique. In Rice Yellow Mottle Virus (RYMV): Economic Importance, Diagnosis and Management Strategies/La panachure jaune du riz : Importance économique, diagnostic et stratégies de gestion. Bouaké, Côte d'Ivoire: West Africa Rice Development Association (WARDA)/Association pour le développement de la riziculture en Afrique de l'Ouest (ADRAO) $p$ 55-59, Proceedings of the First International Symposium on Rice Yellow Mottle Virus (RYMV) vii + 252p

[19] Thibaud B. and Brondeau F. 2001. Une perspective de développement régional autour de l'office du riz est-elle envisageable? Sécheresse 12 : 71-85. 